\title{
PEMBERITAAN HOAX PERSPEKTIF HUKUM PIDANA ISLAM
}

\author{
Lailatul U tiya C hoirroh Jl. DK Gogor V/29 W iyung \\ elaelae836@gmail.com Jajartunggal Surabaya
}

\begin{abstract}
A bstract:This article discusses hoax from the perspective of Islamic criminal law.person who sp read s hoax co ntravenes article 28 (1) of Law N o/ 11/2008 on Information and Electronic Transaction. A ccording toarticle 45 (1) of the same Law, the offender is p unishable with imprisonment of 6 years and/or fine of maximum 1.000.000.000 rupiah. From Islamic perspective, lying is not allowed and Islam does not tolerate sp reading lies or having suspicion to ward s others. Islam encourages goo d, o bjective and factual conversation. From islamc criminal law perspective, spreading hoax is clearly a lie. The suitable punishment for this is imprisonment until he or she repents fromhiso $r$ her wrong doing

Keywords: Hoax, Law of Information and Electronic Transaction, Islamic criminal law
\end{abstract}

Abstrak: Artikel ini membahas tentang tinjauan hukum pidana Islam terhadap pemberitaan hoax. Pelaku penyebaran berita hoax telah melanggar pasal 28 ayat 1 UU Nomor 11 Tahun 2008 tentang ITE, sanksi pidana bagi pelaku penyebar Hoax terdapat dalam pasal 45 ayat (1) yaitu hukuman pidana penjara paling lama enam tahun dan/atau denda paling banyak satu miliar rupiah. Dalam Islam, Islam tidak menghendaki umatnya melakukan perkataan dusta dan kebohongan. Islam tidak menganjurkan fitnah atau berb uruk sangka kep ad a pihak lain. Islam menganjurkan umatnya untuk berbicara dengan pembicaraan yang baik, yang obyektif dan yang benar, bukan perkataan yang kotor dan jorok, bukan pembicaraan yang menghasut, memfitnah, menjelekkan pribadi seseorang, dan bukan pula pembicaraan yang menjurus kepada timbulnya dampak curiga-mencurigai. Dalam hukum pidana Islam, pelaku penyebaran berita hoax yang melanggar pasal 28 ayat 1 UU Nomor 11 T ahun 2008 tentang ITE merup akan tind akan dusta dan fitnah. Hukuman yang tep at bagi pelaku penyebaran berita hoax adalah hukuman ta'zîr yang berupa hukuman kurungan tidak terbatas, terhukum terus dikurung sampai ia bertaubat dan baik pribadinya atau samp ai ia mati.

Kata Kunci: Pemberitaan hoax, Undang-Undang Infomasi dan Transaksi Elektronik, hukum pidana Islam. 


\section{Pendahuluan}

Kemajuan komputer tidak terlepas dari pengaruh globalisasi. G lobalisasi pada hakekatnya adalah proses penetrasi kultur dunia industri maju (Barat) ke belahan dunia non industri, termasuk dunia Islam. Akibatnya hubungan antara Barat dan Islam menjadi tidak seimbang, karena Barat merupakan produsen yang menguasai ilmu pengetahuan dan teknologi serta melahirkan kultur, sedangkan di lain pihak, Islam sebagai konsumen yang menjadi sasaran penetrasi kultur tersebut. ${ }^{1}$

Ciri khas dari globalisasi adalah lancarnya komunikasi dan transportasi, serta lancarnya arus informasi, sehingga sekat wilayah dan budaya menjadi kabur disebabkan kemajuan ilmu pengetahuan dan teknologi. O leh karena itu, dalam era ini teknologi informasi memiliki peran yang sangat signifikan. ${ }^{2}$

Kebutuhan teknologi jaringan komputer, selain sebagai media penyedia informasi, melalui internet pula kegiatan komunitas komersial menjadi bagian terbesar dan terpesat pertumbuhannya serta menembus berbagai batas negara. M elalui jaringan ini kegiatan pasar di dunia bisa diketahui selama 24 jam. M elalui dunia intenet atau disebut juga cyber space, apapun dapat dilakukan. Segi positif dari dunia maya ini tentu saja menambah tren perkembangan teknologi dunia dengan segala bentuk kreatifitas manusia. Namun dampak negatif pun tidak bisa dihindari. Tatkala pornografi marak di media internet, masyarakat pun tak bisa berbuat banyak. Seiring dengan perkembangan teknologi internet, muncul kejahatan yang disebut dengan cyber crimeatau kejahatan melalui jaringan internet.

Munculnya beberapa kasus cyber crime di Indonesia, seperti pencurian kartu kredit, hacking beberapa situs, menyadap transmisi data orang lain, dan penyebaran berita yang belum tentu benar (hoax). Sehingga dalam kejahatan komputer dimungkinkan adanya delik formil dan delik materil. $D$ elik formil adalah perbuatan seseorang yang memasuki komputer orang lain tanpa ijin, sedangkan delik materil adalah perbuatan yang menimbulkan akibat kerugian bagi orang lain.

Berdasarkan hal tersebut diketahui bahwa kecanggihan teknologi komputer disadari telah memberikan kemudahan, terutama dalam

\footnotetext{
${ }^{1}$ A. Basir Solissa, "Kemajuan Barat dan Reaksi Dunia Islam dalam Pandangan Bhasan Tibbi," Jurnal Refleksi, vol. 2, No. 2, Juli 2002, 160.

${ }^{2}$ A mir Syarifudd in, Meretas Keb ekuan ljtihad, ed: A bdul Halim, (Jakarta: Ciputat Press, 2002), 7-8.
} 
membantu pekerjaan manusia. $\mathrm{N}$ amun, perkembangan teknologi komputer menyebabkan munculnya kejahatan-kejahatan baru yaitu dengan memanfaatkan komputer sebagai modus operandinya. Penyalahgunaan komputer dalam perkembangannya menimbulkan persoalan yang sangat rumit, terutama kaitannya dengan proses pembuktian pidana.

Penggunaan komputer sebagai media untuk melakukan kejahatan memiliki tingkat kesulitan tersendiri dalam pembuktiannya. $\mathrm{H}$ al ini dikarenakan komputer sebagai media memiliki karakteristik tersendiri atau berbeda dengan kejahatan konvensional yang dilakukan tanpa komputer. ${ }^{3}$ Kemajuan teknologi informasi (internet) dan segala bentuk manfaat di dalamnya membawa konsekuensi negatif tersendiri, di mana semakin mudahnya para penjahat untuk melakukan aksinya yang semakin merisaukan masyarakat. ${ }^{4}$

Salah satu fenomena yang marak terjadi saat ini adalah banyaknya berita hoax (palsu) yang beredar di medsos (media sosial). M uhammad Alwi Dahlan, ahli komunikasi dari Universitas Indonesia (UI), berpendapat bahwa hoax merupakan manipulasi berita yang sengaja dilakukan dan bertujuan untuk memberikan pengakuan atau pemahaman yang salah. Hal itu sebenarnya sudah terjadi sejak lama, namun kecanggihan teknologi membuat penyebaran kabar tersebut menjadi lebih Iuas dan menjadi prestasi tersendiri bagi sang pembuat hoax jika ia berhasil menyebarluaskannya. ${ }^{5}$

Banyaknya berita hoax (palsu) yang beredar di medsos (media sosial), memiliki dampak besar karena hampir semua orang melihat dan membaca berbagai berita setiap hari, di antara contohnya adalah kasus Jokowi under Cover, di mana Bambang Tri Mulyono, penulis buku Jokowi under Cover, menyebarkan berita bohong yang disampaikan dalam video di laman facebooknya. ${ }^{6}$ Begitu juga berita penyebaran hoax

\footnotetext{
${ }^{3}$ M askum, Kejahatan Cyb er Crime, (Jakarta: Kencana Pranada M edia Group, 2017), 1.

${ }^{4}$ lbid., 47.

5 Nasional Republika, "Hoax Merupakan Kabar Direncanakan" http://nasional.repub lika.co.id/b erita/nasional/hukum/17/01/11/ojm2pv361-ahli-hoax-merupakankabar-yang-direncanakan, diakses pada 19 maret 2017

6 BBC, "Mengapa polisi harus mempidanakan penulis Jokowi Undercover?" http://www.bbc.com/indonesia/indonesia-38496945 di akses pada 9 maret 2017.
} 
tentang penculikan anak disebarkan oleh Angga Permana di wilayah Bandung barat. ${ }^{7}$

Pemberitaan hoax seperti kasus di atas melanggar Pasal 28 ayat (1) dan Pasal 45 ayat (2) U ndang-U ndang N omor 11 T ahun 2008 tentang Informasi dan Traksaksi Elektronik yang berbunyi: ${ }^{8}$

"Setiap orang dengan sengaja dan tanpa hak menyebarkan berita bohong dan menyesatkan yang mengakibatkan kerugian konsumen dalam transaksi elektronik."

"Setiap orang yang memenuhi unsur sebagaimana dimaksud dalam Pasal 28 ayat (1) atau ayat (2) dipidana dengan pidana penjara paling lama 6 (enam) tahun dan/atau denda paling banyak Rp1.000.000.000,00 (satu miliar rupiah)."

Ajaran Islam juga melarang menyebarkan berita tentang keburukan seseorang atau golongan tertentu (ghîbah), apalagi menyebarkan berita yang tidak terbukti kebenarannya (fitnah). I slam muncul sebagai agama yang menyeru umat manusia untuk berbuat kebaikan, kebenaran, dan senantiasa meninggalkan kemungkaran. Oleh sebab itu Islam sebagai agama monotoisme juga merupakan agama yuridis, Islam senantiasa mengkostruksikan kerangka nilai dan norma tertentu pada umatnya, supaya selalu berperilaku berdasarkan pada tatanan hukum yang disepakati. T ata aturan hukum dalam I slam tersebut adalah ketentuan-ketentuan hukum yang didapat dari Alquran dan hadis yang disebut dengan syariah.

Secara umum, tujuan syariah adalah mewujudkan kemaslahatan manusia dengan menjamin kebutuahan pokok (dharûriy) bagi manusia, pemenuhan kebutuhan-kebutuhan (hâjiyyah) dan kebaikan-kebaikan manusia (tahsîniyyah). ${ }^{9}$ Pada tujuan akhirnya, target yang ingin diperoleh dari berbagai aturan tersebut adalah terciptanya tatanan kehidupan yang berkeadilan, aman, dan tenteram sesuai dengan konsep maqâshid al-syarî’ah. 0 leh karena itu, dalam Islam terdapat berbagai aturan hukum yang mengatur seluruh aspek kehidupan berupa sanksi tegas yang merupakan salah satu langkah represif dan preventif dalam mewujudkan tujuan syariat tersebut.

Dengan adanya sanksi yang tegas bagi pelanggar syariah diharapkan seseorang tidak mudah dan tidak seenaknya berbuat jarîmah. Harapan diterapkannya ancaman dan hukuman bagi pelaku jarîmah tersebut adalah

\footnotetext{
${ }^{7}$ Jawap os http ://www.jawap os.com/read/2017/04/06/121421/tersangka-p enyeb ar-b erita-hoax-dibandung-terancam-denda-rp-1-miliar, diakses pada 06 ap ril 2017.

${ }^{8}$ Undang-Undang Nomor 11 Tahun 2008 tentang Informasi dan Transaksi Elektronik.

${ }^{9}$ Abdul W ahab Khallaf, IImu Ushul Fiqih, (Semarang: Dina U tama, 1994), 310.
} 
demi terwujudnya kemaslahatan umat. D engan demikian, tujuan hukum I slam dapat ditegakkan untuk melindungi lima hal yang disebut dengan mashlahah dharûriyyah, yaitu dîn (untuk perlindungan terhadap agama), nafs (jiwa), nas (keturunan), 'aql (akal), dan mâl (harta benda). ${ }^{10}$ Dalam hal ini Allah swt berfirman:

"H ai orang-orang yang beriman, jika datang kepadamu orang fasik membawa suatu berita, maka periksalah dengan teliti, agar kamu tidak menimpakan suatu musibah kepada suatu kaum tanpa mengetahui keadaannya yang menyebabkan kamu menyesal atas perbuatanmu itu". (QS. al-H ujurat: 6). ${ }^{11}$

Dalam ayat ini, Allah melarang hamba-hambaN ya yang beriman berjalan mengikuti desas-desus. Allah menyuruh kaum mukminin memastikan kebenaran berita yang sampai kepada mereka. Tidak semua berita yang dicuplikkan itu benar, dan juga tidak semua berita yang terucapkan itu sesuai dengan fakta.

Allah swt juga mengingatkan bahwa:

"Dan janganlah kamu mengikuti sesuatu yang tidak kamu ketahui. Karena pendengaran, penglihatan, dan hati nurani, semua itu zkan diminta pertanggung jawabannya" (QS Al-Isra' : 36). ${ }^{12}$

'Aid al-Q arni menafsirkan ayat tersebut dengan janganlah kalian mengikuti ataupun meyakini sesuatu yang tidak kalian ketahui kepastiannya. Jadilah orang yang teguh dalam urusanmu, janganlah mengikuti prasangka dan kabar buruk, karena pendengaran, penglihatan, dan hati mausia akan diperhitungkan di hadapan Allah. Jika semua itu dipergunakan untuk kebaikan, maka Allah akan membalasnya dengan pahala, dan jika dipergunakan untuk kejelekan maka allah akan membalasnya dengan siksaan. ${ }^{13}$

D ari permasalahan yang komplek tentang beritahoax di atas, penulis perlu membahas tentang tinjauan hukum pidana Islam terhadap pemberitaan hoax.

\section{Informasi Berita Hoax}

Berita bohong adalah berita yang isinya tidak sesuai dengan kebenaran yang sesungguhnya (materiële waarheid). ${ }^{14}$ Secara singkat,

\footnotetext{
${ }^{10}$ Makhrus M unajat, Dekonstruksi Hukum Pidana Islam, (Yogyakarta: Logung Pustaka, 2004), 5.

${ }^{11}$ Departemen Agama RI, A I-Q ur'an dan Terjemahannya, (Semarang: CV Toha putra, 1971), 846.

${ }^{12} \mathrm{lbid} ., 429$.

${ }^{13}$ 'Aid al-Q arni, Tafsîr al-M uyassar, (Jakarta: Q isthi Press, 2008), 494.

${ }^{14}$ Chazawi Adami dan Ferdian Ardi, Tindak Pidana Pemalsuan, (Jakarta: PT Rajagrafindo Persada, 2016), 236.
} 
informasi hoax adalah informasi yang tidak benar. ${ }^{15}$ Dalam Cambridge Dictionary, ${ }^{16}$ kata hoax sendiri berarti tipuan atau lelucon. Kegiatan menipu, trik penipuan, rencana penipuan disebut dengan hoax. Kemudian, situs $\mathrm{H}$ oaxes.org ${ }^{17}$ dalam konteks budaya mengarahkan pengertian hoax sebagai aktivitas menipu, ketika koran sengaja mencetak cerita palsu, maka disebut hoax. Aksi publisitas yang menyesatkan, ancaman bom palsu, penipuan ilmiah, penipuan bisnis, dan klaim politik palsu merupakan bagian dari sebagai hoax". D engan demikian "informasi hoax" yang dimaksud adalah "informasi tipuan".

Belum banyak literatur mengenai informasi hoax yang dapat ditemui. Harley sendiri membuat sebuah panduan untuk mengenali informasi hoax dan email berantai dikarenakan banyaknya laporan mengenai informasi hoax dan email berantai yang beredar, menimbulkan keresahan di masyarakat. M eskipun sudah dikonfirmasi, usang dan tidak relevan, informasi-informasi ini terus beredar, sehingga panduan untuk mengenali dan mengatasi hoax menjadi sangat penting.

Ciri-ciri informasi hoax yang dikemukakan $\mathrm{H}$ arley ada empat, yaitu memuat kalimat yang mengajak untuk menyebarkan informasi seluasluasnya, tidak mencantumkan tanggal dan deadline, tidak mencantumkan sumber yang valid dan memakai nama dua perusahaan besar. Keempat ciri ini setidaknya dapat membantu seseorang dalam memfokuskan lokus pemikirannya ketika berhadapan dengan sebuah informasi, sehingga dapat bersikap skeptis terhadap setiap informasi yang ditemui sekalipun terlihat benar, lengkap, dan sangat meyakinkan. ${ }^{18}$

Situs hoaxbusters menyebutkan beberapa jenis hoax, antara lain hoax hadiah (menyebutkan bahwa anda memenangkan sejumlah hadiah), hoax simpati (menyebarkan informasi tentang orang yang sakit, butuh bantuan atau penculikan) dan urband legend (menyebarkan tentang parfum merek tertentu tidak tahan lama baunya). H arley mengatakan bahwa informasi hoax masih akan terus berkembang seiring dengan perkembangan kemajuan jaman. Ada juga informasi yang pada esensinya

\footnotetext{
${ }^{15}$ hoaxbuster http://www.hoaxbusters.org/hoax10.html, diakses tanggal 04 ap ril 2017.

16 dictionary.cambridge http://dictionary.cambridge.org/dictionary/english/hoax\#translations, diakses tanggal 20 A p ril 2017.

${ }^{17} \mathrm{lbid}$.

${ }^{18}$ Clara Novita, Literasi Media Baru dan Penyebaran Informasi Hoax Studi Fenomenologi Pada Pengguna Whatsapp dalam Penyebaran Informasi Hoax Periode Januari-maret 2015, (TesisYogyakarta: Universitas Gad jah Mada, 2016).
} 
benar tetapi kegunaan dan nilainya dipertanyakan, disebut $\mathrm{H}$ arley dengan semi-hoax. ${ }^{19}$

\section{T indak Pidana Pemberitaan H oax}

Tindak pidana sengaja dan tanpa hak menyebarkan berita bohong yang menyebabkan kerugian konsumen transaksi elektronik dan menyebarkan informasi untuk menimbulkan rasa kebencian atau permusuhan tertuang dalam pasal 28 jo 45 ayat(2). Jika pasal 28 jo 45 ayat (2) UU ITE dirumuskan dalam satu naskah, selengkapnya adalah sebagai berikut:20

"Setiap orang dengan sengaja dan tanpa hak menyebarkan berita bohong dan menyesatkan yang mengakibatkan kerugian konsumen dalam transaksi elektronik, dipidana dengan pidana penjara paling lama 6 (enam) tahun dan/atau denda paling banyak Rp. 1000.000.000,00 (satu milliard rupiah)“ "D ipidana yang sama seperti ayat (1) setiap orang dengan sengaja dan tanpa hak menyebarkan informasi yang ditujukan untuk menimbulkan rasa kebencian atau permusuhan individu dan/atau kelompok masyarakat tertentu berdasarkan atas suku, agama, ras, dan antar golongan (SARA). "

Ada dua bentuk tindak pidana ITE dalam pasal 28, masing-masing dirumuskan dalam ayat (1) dan ayat (2). ${ }^{21}$ T indak pidana ITE dalam ayat

(1) terdiri dari unsur-unsur berikut:

1. Kesalahan: dengan sengaja.

2. M elawan hukum: tanpa hak.

3. Perbuatan: menyebarkan.

4. O bjek: berita bohong dan meyesatkan.

5. Akibat konstitutif: mengakibatkan kerugian konsumen dalam transaksi elektronik.

Unsur-unsur tindak pidana dalam ayat (2) adalah:

1. Kesalahan: dengan sengaja.

2. M elawan hukum: tanpa hak.

3. Perbuatan: menyebarkan.

4. O bjek: informasi.

5. Tujuan: untuk menimbulkan rasa kebencian atau permusuhan individu dan/atau kelompok masyarakat tertentu berdasarkan atas suku, agama, ras, dan antar golongan (SARA).

\footnotetext{
${ }^{19}$ hoaxbuster http://www.hoaxbusters.org/hoax10.html, diakses tanggal 04 ap ril 2017.

${ }^{20}$ Undang-Undang N omor 11 Tahun 2008 tentang Informasi dan Transaksi Elektronik.

${ }^{21}$ Adami Chazawi \& Ardi Ferdian, Tindak Pidana Informasi dan Transaksi Elektronik, (Malang: Media Nusa Creative, 2015), 128.
} 
Unsur-unsur formal yang membentuk rumusan tindak pidana secara materil dan formal.

\section{Bentuk pertama dirumuskan secara materil}

T indak pidana ITE pertama dirumuskan secara materiil. Tindak pidana tersebut selesai sempurna bila akibat perbuatan telah timbul. Perbuatan menyebarkan berita bohong yang menyesatkan telah menimbulkan akibat adanya kerugian konsumen dalam transaksi elektronik.

Dalam hubungannya dengan unsur-unsur lain, sengaja artinya si pembuat menghendaki untuk menyebarkan berita bohong dan menyesatkan, dan menghendaki atau setidaknya menyadari timbul akibat kerugian konsumen dalam transaksi elektronik. Si pembuat juga mengerti bahwa apa yang dilakukannya itu tidak dibenarkan (sifat melawan hukum subjektif), dan memberi berita yang isinya bohong dan mengerti dengan demikian akan mengakibatkan kerugian bagi konsumen transaksi elektronik. Transaksi elektronik adalah perbuatan hukum yang dilakukan dengan mengunakan komputer dan/atau media elektronik lainnya. ${ }^{22}$

Sifat melawan hukum dirumuskan dalam frasa "tanpa hak" bercorak dua; objektif dan subjektif. Corak objektif ialah sifat selamanya perbuatan tersebut diletakkkan pada kebohongan dan menyesatkan dari isi berita yang disebarkan, sementara corak subjektif terletak pada kesadaran isi pembuat tentang dicelanya perbuatan semacam itu di masyarakat yang diformalkan dalam undang-undang. Bila dilihat dari sudut sifat tercelanya perbuatan yang diletakkan pada isi berita dan akibatnya bagi pengguna konsumen transaksi elektronik, maka mencantumkan unsur "tanpa hak" dirasa berlebihan oleh sebab tidak mungkin terdapat adanya orang yang menyebarkan berita bohong yang menyesatkan kerugian konsumen transaksi elektronik yang dibolehkan.

Apakah mungkin disebabkan karena pembentukan UU ITE menganggap, bahwa "tanpa hak" diletakkan pada si pembuat yang "tidak memiliki" sarana sistem elektronik yang digunakannya? M isalnya mengirim email dengan menggunakan alamat email orang lan tanpa ijin dari pemiliknya apabila yang dimaksud demikian, mestinya bukan frasa "tanpa hak" yang digunakan dalam rumusan, melainkan "tanpa ijin". $\mathrm{N}$ amun pendapat inipun menjadi lemah, kalau dilihat dari perbuatan melakukan transaksi elektronik dengan menggunakan sistem elektronik

22 Ibid., 129. 
milik orang lain tanpa ijin dari yang berhak seperti itu, sebenarnya merupakan tindak pidana yang berdiri sendiri, dan masuk pada pasal $30 .^{23}$

Kiranya pembentukan UU ITE telah lupa keterangan M vTW vS tentang latar belakang dalam hal apa unsur sifat melawan hukum itu perlu dicantumkan salam rumusan. UU ITE yang memutarbalik doktrin hukum dalam M vT. Yang menyatakan bahwa unsur melawan hukum perlu dicantumkan di dalam rumusan tindak pidana, hanya apabila dirasakan perbuatan itu dapat dilakukan orang yang berhak. M isalnyajika mendapatkan ijin dari yang berhak. U ntuk menghindarkan agar tindak pidananya bagi mereka yang berhak melakukan perbuatan semacam itu, maka perlu unsur sifat melawan hukum yang dicantumkan dalam rumusan tindak pidana. ${ }^{24}$

Berita bohong adalah berita yang isinya tidak sesuai dengan kebenaran sesungguhnya (materiële waarheid). M enyebarkan maksudnya menyampaikan (berita bohong) pada khalak umum in casu melalui media sistem elektronik. M enyebarkan berita bohong tidak bisa ditujukan pada satu atau seseorang tertentu. M elainkan harus pada banyak orang (umum). Sesuai dengan frasa "menyesatkan" berita bohong itu dapat memperdaya orang. Sifat memperdaya dari isi berita bohong yang disebarkan yang menyesatkan umum, sehingga menimbulkan akibat kerugian konsumen yang melakukan transaksi elektronik.

Kerugian yang dimaksud, tidak saja kerugian yang dapat dinilai uang, tetapi segala bentuk kerugian. M isalnya timbulnya perasaan cemas, malu, kesusahan, hilangnya harapan mendapatkan kesenangan atau keuntungan dan sebagainya

2. Bentuk kedua dirumuskan secara formal

Kesamaan dengan bentuk pertama, ialah mengenai unsur sengaja, tanpa hak dan perbuatan menyebarkan. U nsur-unsur yang sama tidak perlu dibicarakan lagi.

Kalau bentuk pertama secara jelas merupakan tindak pidana materiil. Dari frasa "mengakibatkan menyesatkan" sangat jelas, disyaratkan akibat harus timbul agar tindak pidana menjadi selesai sempurna. Bentuk kedua tidak begitu jelas. Ketidakjelasan itu bisa menimbulkan perbedaan pendapat.

\footnotetext{
${ }^{23} \mathrm{lbid}$.

${ }^{24}$ Jan Remmelink, Hukum Pidana (Komentar atas Pasal-Pasal Terpenting dari Kitab Undang Undang Hukum Pidana Belanda dan Padanannya dalam Kitab Undang-Undang Pidana Indonesia), (Jakarta: Gramedia Pustaka, 2003), 184.
} 
Pendapat pertama, merupakan tindak pidana formil. Selesainya tindak pidana diletakkan pada selesainya perbuatan. Alasannya dalam rumusan tidak secara tegas melarang menimbulkan akibat tertentu. Frasa "ditujukan untuk".... . bisa diartikan bahwa perbuatan menyebarkan informasi ditujukan agar timbul rasa kebencian dan sebagainya. Artinya tujuan tidak berbeda dengan "maksud". Sedangkan rasa kebencian antar agama atau antar golongan dan sebagainya tidak perlu benar-benar telah timbul oleh perbuatan. ${ }^{25}$

Pendapat ini memerlukan pembuktian, bahwa perbuatan menyebarkan ditujukan agar timbulnya rasa kebencian dan sebaginya. C aranya dengan melogikan wujud perbuatan seperti itu menurut sifat dan keadaannya dapat menimbulkan kebencian antara golongan dan sebagainya, yang semula disadari dan di hendaki si pembuat. M elogikan ini harus disertai dengan pengungkapan keadaan-keadaan/fakta yang ada sekitar dan pada saat perbuatan dilakukan, sifat dan keadaan isi informasi yang disebarkan, latar belakang objektif dan subjektif si pembuat, dan sebagainya. Kiranya sama seperti dengan cara membuktikan unsur sengaja.

Pendapat kedua, termasuk tindak pidana materiil. Tindak pidana selesai sempurna akibat adanya rasa kebencian atau permusuhan antar kelompok masyarakat telah timbul. Alasannya ada dua pertama, cara merumuskan kedua sama persis dengan cara merumuskan tindak pidana penipuan (oplichting) pasal 378, atau pemerasan pasal 368 KU H P. T idak terdapat perbedaan pendapat mengenai penipuan dan pemerasan tersebut adalah tindak pidana materiil. ${ }^{26}$

Alasan pendapat kedua ialah dalam hubungannya dengan pembuktian. Rasa kebencian merupakan rasa tidak senang atau tidak suka. Rasa permusuhan merupakan perasaan orang/kelompok lainnya adalah musuhnya. Rasa permusuhan lebih tajam lebih besar rasa tidak senangnya, karena orang atau kelompok lain adalah hati. Tidak bisa diketahui dan dibuktikan sebelum ada wujud nyata dari tindakan yang menghambarkan rasa ketidak senangan atau perumusan harus benar-benar sudah ada wujudnya, bukan sekedar masih disimpan didalam hati masing-masing orang. Dalam hal pendapat kedua, jika perbuatan telah terwujud sementara akibat tidak timbul, kejadian itu masuk percobaan, sedangkan pembuatannya sudah dapat dipidana.

\footnotetext{
${ }^{25}$ Adami Chazawi \& Ardi Ferdian, T indak Pidana Informasi dan Transaksi Elektronik, 132. ${ }^{26} \mathrm{lbid}$
} 


\section{T indak Pidana di Bidang M edia Sosial}

M enurut Kitab U ndang-Undang H ukum Pidana (KUH P) istilah umum yang dipakai adalah tindak pidana karena bersifat netral, dan pengertian tersebut meliputi perbutan pasif dan aktif. Jadi dapat dikatakan bahwa pengertian tindak pidana mempunyai arti perbuatan melawan hukum atau tidak melakukan sesuatu yang oleh peraturan perundangundangan dinyatakan sebagai perbuatan yang dilarang dan diancam dengan pidana.

Pada tanggal 21 April 2008, ditandai dengan diundangkannya U ndang-U ndang nomor 11 tahun 2008 tentang I nformasi dan T ransaksi Elektronik (lembaran negara tahun 2008 nomor 58, tambahan lembaran negara nomor 4843. Untuk selanjutnya disingkat UU ITE (Undang U ndang Informasi dan Transaksi Elekrtonik). ${ }^{27}$

Undang-Undang N omor 11 Tahun 2008 tentang Informasi dan Transaksi Elekrtonik ini kemudian diubah dengan Undang-U ndang N omor 19 Tahun 2016 tentang Perubahan U ndang-U ndang N omor 11 Tahun 2008 Informasi dan Transaksi Elekrtonik. ${ }^{28}$ Diundangkannya U ndang-Undang Informasi dan Transaksi Elekrtonik ini menunjukkan bahwa bangsa Indonesia, tidak ingin ketinggalan dalam kancah perkembangan teknologi informasi, khususnya dalam rangka mencegah penyalahgunaan pemanfaatan teknologi informasi. terkait dengan pencegahan ini, dalam undang undang informasi dan transaksi elektronik, telah diatur tentang perbuatan-perbuatan apa saja yang dilarang dan juga ancaman sanksi pidana bagi siapa saja yang melanggar larangan tersebut.

Tidak dapat dipungkiri sebagaimana disebutkan dalam penjelasan umum Undang-Undang Informasi dan Transaksi Elektronik, bahwa Teknologi Informasi saat ini menjadi pedang bermata dua, oleh karena selain memberikan kontribusi bagi peningkatan kesejahteraan, kemajuan dan peradaban manusia, sekaligus menjadi sarana efektif perbuatan melawan H ukum.

Selanjutnya disebutkan bahwa sekarang ini telah lahir rezim $\mathrm{H}$ ukum baru yang dikenal dengan $\mathrm{H}$ ukum Siber atau $\mathrm{H}$ ukum T elematika, $\mathrm{H}$ ukum Teknologi Informasi (Law of Information Technology), Hukum D unia

\footnotetext{
27 Didik Endro Purwoleksono, "Seminar Peran Aktif Masyarakat Mengbadapi Hoax di Media Sosial,Peran A ktif Masyarakat M engbadap i Hoax di M ed ia Sosial "16 Maret 2017", 1.

${ }^{28} \mathrm{lbid}$.
} 
M aya (V irtual W ord Law), H ukum M ayantara. istilah yang dikenal untuk tindak pidana di bidang ITE adalah Cyber C rime. ${ }^{29}$

Pemerintah perlu mendukung pengembangan T eknologi Informasi melalui Infrastruktur Hukum dan pengaturannya sehingga pemanfaatan Teknologi Informasi dilakukan secara aman untuk mencegah penyalahgunaanya dengan memperhatikan nilai-nilai agama dan sosial budaya masyarakat Indonesia. Ciri-ciri tindak pidana di bidang ite antara lain yaitu:

1. Dilakukan oleh orang pintar

2. M enggunakan teknik yang canggih dan rumit untuk dapat dibuktikan jika hanya dengan pasal-pasal pidana konvensional (KU H P)

3. Berdimensi yang lebih luas daripada tindak pidana biasa

4. M erupakan ciri khas masyarakat "abad millennium" sekarang ini yaitu: ditandai dengan era "Cyber" (dunia maya/dunia mayantara/siber) masyarakat informasi tidak ada batasan territorial (Borderless), artinya yang ada adalah batasan "T echnology". Yang jauh sekarang menjadi dekat paper-based menjadi paperless informasi begitu cepat menyebar perdagangan Via Elektronik. ${ }^{30}$

\section{H ukuman bagi Pelaku Pemberitaan $\mathrm{H}$ oax}

H oax sendiri memiliki definisi yaitu suatu berita atau pernyataan yang memiliki informasi yang tidak valid atau berita palsu yang tidak memiliki kepastian yang sengaja disebar luaskan untuk membuat keadaan menjadi heboh dan menimbulkan ketakutan. Akan tetapi, ada juga hoax yang sengaja dibuat untuk membuat cara berpikir tentang suatu hal menjadi sesat karena tertipu berita atau opini hoax. Jika sebelumnya hoax ini disebar luaskan lewat sms ataupun email dengan banyak, maka hoax sekarang ini lebih banyak beredar di dalam sosial media seperti I nstagram, facebook, T witter, Path, Whatsapp, serta blog-blog tertentu.

Tindak pidana merupakan pengertian dasar dalam hukum pidana. Tindak pidana merupakan suatu pengertian yuridis, lain halnya dengan istilah perbuatan jahat atau kejahatan. Secara yuridis formal, tindak kejahatan merupakan bentuk tingkah laku yang melanggar undangundang pidana. O leh sebab itu, setiap perbuatan yang dilarang oleh undang-undang harus dihindari dan arang siapa melanggarnya maka akan dikenakan pidana. Jadi larangan-larangan dan kewajiban-kewajiban

${ }^{29} \mathrm{lbid}$.

${ }^{30} \mathrm{lbid}$. 
tertentu yang harus ditaati oleh setiap warga negara wajib dicantumkan dalam undang-undang maupun peraturan-peraturan pemerintah, baik di tingkat pusat maupun daerah. ${ }^{31}$

Tindak Pidana adalah kelakuan manusia yang dirumuskan dalam U ndang-undang, melawan hukum, yang patut dipidana dan dilakukan dengan kesalahan.

Orang yang melakukan perbuatan pidana akan mempertanggungjawabkan perbuatan dengan pidana apabila ia mempunyai kesalahan, seseorang mempunyai kesalahan apabila pada waktu melakukan perbuatan dilihat dari segi masyarakat menunjukkan pandangan normatif mengenai kesalahan yang dilakukan. ${ }^{32}$

Tindak pidana adalah perbuatan melakukan atau tidak melakukan sesuatu yang memiliki unsur kesalahan sebagai perbuatan yang dilarang dan diancam dengan pidana, di mana penjatuhan pidana terhadap pelaku adalah demi terpeliharanya tertib hukum dan terjaminnya kepentingan umum. ${ }^{33}$

Jenis-jenis tindak pidana dibedakan atas dasar-dasar tertentu, sebagai berikut: ${ }^{34}$

1. M enurut Kitab U ndang-U ndang H ukum Pidana (KUH P) dibedakan antara lain kejahatan yang dimuat dalam Buku II dan Pelanggaran yang dimuat dalam Buku III. Pembagian tindak pidana menjadi "kejahatan" dan "pelanggaran" itu bukan hanya merupakan dasar bagi pembagian KUHP kita menjadi Buku ke II dan Buku ke III melainkan juga merupakan dasar bagi seluruh sistem hukum pidana di dalam perundang-undangan secara keseluruhan.

2. M enurut cara merumuskannya, dibedakan dalam tindak pidana formil (formeel Delicten) dan tindak pidana materil ( $M$ ateriil $D$ elicten). Tindak Pidana formil adalah tindak pidana yang dirumuskan bahwa larangan yang dirumuskan itu adalah melakukan perbuatan tertentu, misalnya Pasal 362 KUH P yaitu tentang pencurian. Tindak pidana materil inti larangannya adalah pada menimbulkan akibat yang

\footnotetext{
${ }^{31}$ P.A.F. Lamintang, Dasar-Dasar Hukum Pidana Indonesia, (Bandung: PT . Citra Adityta Bakti, 1996), 7.

${ }^{32}$ Andi Hamzah, Bunga Rampai Hukum Pidana dan Acara Pidana, (Jakarta: Ghalia Indonesia, 2001), 22.

${ }^{33}$ P.A.F. Lamintang, Dasar-Dasar Hukum Pidana Ind onesia... , 16.

${ }^{34}$ Andi Hamzah. Bunga Rampai Hukum Pidana dan Acara Pidana... .., 25-27.
} 
dilarang, karena itu siapa yang menimbulkan akibat yang dilarang itulah yang dipertanggungjawabkan dan dipidana.

3. M enurut bentuk kesalahan, tindak pidana dibedakan menjadi tindak pidana sengaja (dolus delicten) dan tindak pidana tidak sengaja (culpose delicten). Contoh tindak pidana kesengajaan (dolus) yang diatur di dalam KUH P antara lain sebagai berikut: Pasal 338 KU HP (pembunuhan) yaitu dengan sengaja menyebabkan hilangnya nyawa orang lain, Pasal 354 KU H P yang dengan sengaja melukai orang lain. Pada delik kelalaian (culpa) orang juga dapat dipidana jika ada kesalahan, misalnya Pasal 359 KUHP yang menyebabkan matinya seseorang, contoh lainnya seperti yang diatur dalam Pasal 188 dan Pasal 360 KUHP.

4. Menurut macam perbuatannya, tindak pidana aktif (positif), perbuatan aktif juga disebut perbuatan materil adalah perbuatan untuk mewujudkannya diisyaratkan dengan adanya gerakan tubuh orang yang berbuat, misalnya pencurian (Pasal 362 KUHP) dan penipuan (Pasal 378 KUH P). Tindak pidana pasif dibedakan menjadi tindak pidana murni dan tidak murni. Tindak pidana murni, yaitu tindak pidana yang dirumuskan secara formil atau tindak pidana yang pada dasarnya unsur perbuatannya berupa perbuatan pasif, misalnya diatur dalam Pasal 224,304 dan 552 KUH P.T indak pidana tidak murni adalah tindak pidana yang pada dasarnya berupa tindak pidana positif, tetapi dapat dilakukan secara tidak aktif atau tindak pidana yang mengandung unsur terlarang tetapi dilakukan dengan tidak berbuat, misalnya diatur dalam Pasal 338 KUH P, ibu tidak menyusui bayinya sehingga anak tersebut meninggal.

Berdasarkan uraian di atas, dapat diketahui bahwa jenis-jenis tindak pidana terdiri dari tindak pidana kejahatan dan tindak pidana pelanggaran, tindak pidana formil dan tindak pidana materil, tindak pidana sengaja dan tindak pidana tidak sengaja serta tindak pidana aktif dan pasif.

Unsur-unsur tindak pidana memiliki 5 (lima) macam sebagai berikut: ${ }^{35}$

a. Kelakuan dan akibat (perbuatan)

b. $\mathrm{H}$ al ikhwal atau keadaan yang menyertai perbuatan

c. Keadaan tambahan yang memberatkan pidana

${ }^{35} \mathrm{lbid}$. 
d. Unsur melawan hukum yang objektif

e. Unsur melawan hukum yang subyektif

Berdasarkan pemaparan di atas, maka bisa dikatakan bahwa penyebaran berita hoax atau kabar bohong melanggar pasal 28 ayat $1 \mathrm{UU}$ N omor 11 T ahun 2008 Tentang ITE yang berbunyi: ${ }^{36}$

"Setiap orang dengan sengaja dan tanpa hak menyebarkan berita bohong dan menyesatkan yang mengakibatkan kerugian konsumen dalam transaksi elektronik."

Dalam pasal 28 ayat (1) memenuhi unsur :

1. Setiap orang di sini adalah ditujukan kepada pelaku penyebar berita bohong/hoax

2. Kesalahan: dengan sengaja. Dengan sengaja yang dapat diartikan bentuk kesengajaan dan tanpa hak menyebarkan berita bohong dan menyesatkan, terbukti melakukan dalam hal melaksanakan delik yang diancamkan dalam pasal tersebut.

3. M elawan hukum: tanpa hak, disini tanpa hak diartikan sebagai melawan hukum yaitu tanpa adanya hak sendiri (zonder eigen recht), bertentagan dengan hukum pada umumnya (in strijd met het recht in het algemeen), bertentangan dengan hak pribadi seseorang (in strijd met een anders subjectieve recht), bertentangan dengan hukum objektif (tegen het objectieve recht), dalam penyebaran berita bohong atau Hoax merupakan tindakan yang melawan hukum dan bertentangan dengan hak pribadi

4. Perbuatan: menyebarkan seseorang karena telah menyebarkan berita tidak sesuai dengan fakta.

5. O bjek: berita bohong sama artinya dengan bersifat palsu, artinya sesuatu yang disiarkan itu mengandung hal yang tidak benar. Ada persamaan dengan bersifat menyesatkan, ialah isi apa yang disiarkan mengandung hal yang tidak sebenarnya dan menyesatkan memberitahukan suatu kabar yang kosong, akan tetapi juga menceritakan secara tidak betul tentang suatu kejadian. Suatu berita yang menceritakan secara tidak betul tentang suatu kejadian, karena rumusan unsur menggunakan kata "dan", artinya kedua unsurnya harus terpenuhi untuk pemidanaan, yaitu menyebarkan berita bohong (tidak sesuai dengan hal/keadaan yang sebenarnya) dan menyesatkan

\footnotetext{
${ }^{36}$ Undang-Undang N omor 11 Tahun 2008 tentang Informasi dan Transaksi Elektronik.
} 
(menyebabkan seseorang berpandangan pemikiran salah/keliru). Apabila berita bohong tersebut tidak menyebabkan seseorang berpandangan salah, maka tidak dapat dilakukan pemidanaan.

6. Akibat konstitutif: mengakibatkan kerugian konsumen dalam transaksi elektronik. Yang mengakibatkan kerugian konsumen dalam transaksi elektronik adalah semua bentuk kerugian, tidak saja kerugian yang dapat dinilai uang, tetapi segala bentuk kerugian. $M$ isalnya, timbulnya perasaan cemas, malu, kesusahan, hilangnya harapan mendapatkan kesenangan atau keuntungan sebagianya.Unsur yang terakhir ini mensyaratkan berita bohong dan menyesatkan tersebut harus mengakibatkan suatu kerugian konsumen. Artinya, tidak dapat dilakukan pemidanaan, apabila tidak terjadi kerugian konsumen di dalam transaksi elektronik.

Sanksi pidana pasal 28 ayat (1) terdapat pada pasal 45 ayat (1) yaitu hukuman pidana penjara paling lama 6 (enam) tahun dan/atau denda paling banyak Rp. 1.000.000.000,00 (satu miliar rupiah).

\section{Analisis H ukum Pidana Islam terhadap Pemberitaan H oax}

Dalam perspektif Islam, menyebarkan hoax termasuk perbuatan ghîbah menceritakan tentang seseorang yang tidak berada di tempat dengan sesuatu yang tidak disukainya, baik menyebutkan aib badannya, keturunannya, akhlaknya, perbuatanyya, urusan agamanya, dan urusan dunianya. ${ }^{37}$ Sebagaimana dalam hadis dijelaskan tentang ghîbah yaitu:

"D ari Abu Hurairah, sesungguhnya Rasulullah saw bersabda: Tahukah kalian apa ghibah itu? Sahabat menjawab Allah dan Rasul-N ya yang lebih mengetahui. Beliau bersabda: "kamu menyebutkan saudaramu dengan sesuatu yang ia benci, "Beliau ditanya: Bagaimana kalau memang saudaraku melakukan apa yang kukatakan? Beliau menjawab: kalau memang sebenarnya begitu berarti engkau telah mengghibahnya, tetapi jika apa yang kau sebutkan tidak benar maka berarti engkau telah berdusta atasnya. $^{38}$

Berdasarkan hadis di atas ghîbah diartikan dengan menyatakan tentang sesuatu yang terdapat pada diri seorang muslim di saat ia tidak berada di tempat, dan apa yang disebutkan memang ada pada orang tersebut tetapi ia tidak suka hal tersebut dinyatakan. Adapun jika yang disebutkan tidak ada padanya, berarti telah memfitnahnya.

\footnotetext{
${ }^{37}$ Hassan sa'udi \& A hmad Hasan Irab i, Jerat-Jerat Lisan, (Solo: Pustaka A rofah, 2004), 14.

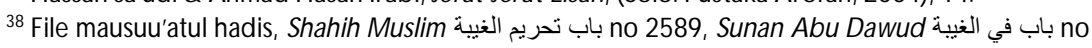
4874, باب ماجاء في الغيبة no 2741, Sunan At-T irmidzi, باب ماجاء في الغيبة no 1999.
} 
Allah swt tidak menghendaki umatN ya melakukan perkataan dusta dan kebohongan, Islam tidak menganjurkan fitnah atau berburuk sangka kepada pihak lain. U ntuk itulah, I slam telah menetapkan sejumlah norma kebebasan berbicara, misalnya: hendaklah pembicaraan yang diucapkan itu pembicaraan yang baik, bukan perkataan yang kotor dan jorok, bukan pembicaraan yang menghasut, memfitnah, menjelekkan pribadi seseorang, dan bukan pula pembicaraan yang menjurus kepada timbulnya dampak curiga-mencurigai. Hendaklah apa yang dibicarakan itu perkataan yang obyektif dan benar.

A papun yang diucapkan seseorang, harus dipertanggungjawabkan kebenaran isinya kepada Allah dan manusia. ${ }^{39}$ Berita yang beredar memang harus diteliti lagi, Isu dapat membahayakan dan merugikan banyak orang. Ini sesuai dengan peringatan yang disampaikan al-Q ur'an.

Dalam hal ini Allah swt berfirman:

"H ai orang-orang yang beriman, jika datang kepadamu orang fasik membawa suatu berita, maka periksalah dengan teliti, agar kamu tidak menimpakan suatu musibah kepada suatu kaum tanpa mengetahui keadaannya yang menyebabkan kamu menyesal atas perbuatanmu itu". (Al-H ujurat: 6). ${ }^{40}$

Dalam ayat ini terdapat pelajaran adab bagi orang yang beriman dalam menghadapi suatu isu atau berita yang belum jelas kebenarannya.bahwa dengan tidak menyebarkan berita bohong atau hoax merupakan ibadah yang dapat meningkatkan iman jika kita menyebarkan berita bohong atau hoax dapat berdampak pada kerusakan hubungan pribadi dan masyarakat. Penyesalan akan dirasakan pada orang yang menuduh tanpa meneriksa berita terlebih dahulu. Penyesalan di dunia maupun diakhirat akan ditimpakan kepada orang yang menerima isu negatif, serta kepada orang yang menyebarkan berita bohong atau hoax.

Allah swt juga mengingatkan bahwa:

"Dan janganlah kamu mengikuti sesuatu yang tidak kamu ketahui. Karena pendengaran, penglihatan, dan hati nurani, semua itu akan diminta pertnggung jawabannya" (QS Al-Isra' : 36). ${ }^{41}$

Janganlah kalian mengikuti ataupun meyakini sesuatu yang tidak kalian ketahui kepastiannya. Jadilah orang yang teguh dalam urusanmu, janganlah

\footnotetext{
${ }^{39}$ Basri Iba Asghary, Solusi AI-Q ur'an tentang Problema Sosial Politik Budaya, (Jakarta: Rineka Cipta, 1994), 255.

${ }^{40}$ Depag RI, AI-Q ur'an dan Terjemahannya, 846.

${ }^{41}$ Ibid., 429 .
} 
mengikuti prasangka dan kabar buruk, karenapendengaran, penglihatan, dan hati manusia akan diperhitungkan di hadapan Allah. Jika semua itu dipergunakan untuk kebaikan, maka Allah akan membalasnya dengan pahala, dan jika dipergunakan untuk kejelekan makaAllah akan membalasnya dengan siksaan. ${ }^{42}$

Dalam hukum pidana di Indonesia pelaku menyebar berita hoax dikenai sanksi dalam pasal 45 ayat (2) yang berbunyi: ${ }^{43}$

"Setiap orang yang dengan sengaja dan tanpa hak menyebarkan berita bohong dan menyesatkan yang mengakibatkan kerugian konsumen dalam Transaksi Elektronik sebagaimana dimaksud dalam Pasal 28 ayat (1) dipidana dengan pidana penjara paling lama 6 (enam) tahun dan/atau denda paling banyak Rp1.000.000.000,00 (satu miliar rupiah)".

Dalam pasal 45 ayat (2) memenuhi unsur:

1. Setiap orang mengandung arti semua orang arti setiap orang disini adalah ditunjukkan kepada pelaku.

2. Dengan sengaja dan tanpa hak menyebarkan berita bohong dan menyesatkan. D engan sengaja yang dapat diartikan bentuk kesengajaan dan tanpa hak menyebarkan berita bohong dan menyesatkan,terbukti melakukan dalam hal melaksanakan delik yang diancamkan dalam pasal tersebut.

3. M engakibatkan kerugian konsumen mengakibatkan kerugian konsumen dalam transaksi elektronik. Yang mengakibatkan kerugian konsumen dalam transaksi elektronik adalah semua bentuk kerugian, tidak saja kerugian yang dapat dinilai uang, tetapi segala bentuk kerugian. M isalnya, timbulnya perasaan cemas, malu, kesusahan, hilangnya harapan mendapatkan kesenangan atau keuntungan sebagianya.U nsur yang terakhir ini mensyaratkan berita bohong dan menyesatkan tersebut harus mengakibatkan suatu kerugian konsumen. Artinya, tidak dapat dilakukan pemidanaan, apabila tidak terjadi kerugian konsumen di dalam transaksi elektronik.

4. Dengan menggunakan media elektronik, orang yang melakukan perbuatan hukum yang dilakukan dengan menggunakan komputer, jaringan komputer, dan atau media elektronik lainnya.

5. Dengan menyalagunakan perbuatan Pasal 28 ayat (1) dipidana 6 (enam) tahun / dendan Rp.1.000.000.000,00.

Dengan adanya sanksi yang tegas bagi pelanggar syara' diharapkan seseorang tidak mudah dan tidak seenaknya berbuat jarîmah. $\mathrm{H}$ arapan

42 'Aidh al-Q arni, Tafsir al-M uyassar, 494.

${ }^{43}$ Undang-Undang N omor 11 Tahun 2008 tentang Informasi dan Transaksi Elektronik. 
diterapkannya ancaman dan hukum bagi pelaku jarîmah tersebut adalah demi terwujudnya kemaslahatan umat. D engan demikian, tujuan hukum Islam ditegakkan untuk melindungi lima hal yang disebut dengan mashlahah dharûriyyah, yaitu: ${ }^{44}$

1. Dîn (untuk perlindungan terhadap agama). Agama di sini maksudnya adalah sekumpulan akidah, ibadah, hukum, dan undang-undang yang dibuat oleh Allah untuk mengatur hubungan manusia dengan Tuhannya dan juga mengatur hubungan antar manusia. Untuk menjaga dan memelihara kebutuhan agama ini dari ancaman musuh maka Allah mensyariatkan hukum berjihad untuk memerangi orang yang menghalangi dakwah agama. U ntuk menjaga agama ini Allah juga mensyariatkan shalat dan melarang murtad dan syirik. Jika ketentuan ini diabaikan, maka akan terancamlah eksistensi agama tersebut, dan Allah menyuruh memerangi orang yang murtad dan musyrik. Dengan demikian, tujuan hukum I slam ditegakkan untuk melindungi lima hal yang disebut dengan mashlahah dharûriyyah, yaitu dîn (untuk perlindungan terhadap agama), nafs (jiwa), nas (keturunan), 'aql (akal), dan mâl (harta benda). ${ }^{45}$

2. Nafs (jiwa), Untuk memelihara jiwa ini Allah mewajibkan berusaha untuk mendapatkan kebutuhan makanan, minuman, pakaian, dan tempat tinggal. T anpa kebutuhan tersebut maka akan terancamlah jiwa manusia. Allah juga akan mengancam dengan hukuman qishash (hukum bunuh) atau diat (denda) bagi siapa saja yang menghilangkan jiwa. Begitu juga Allah melarang menceburkan diri ke jurang kebinasaan (bunuh diri).

3. Nas (keturunan), untuk memelihara keturunan Allah mensyariatkan pernikahan dan sebaliknya mengharamkan perzinaan. O rang yang mengabaikan ketentuan ini, akan terancam eksistensi keturunannya. Bahkan kalau larangan perzinaan ini dilanggar, maka Allah mengancam dengan hukuman rajam atau hukuman cambuk seratuskali.

4. 'aql (akal), untuk menjaga dan memelihara akal ini Allah mengharuskan manusia mengkonsumsi makanan yang baik dan halal serta mempertinggi kualitas akal dengan menuntut ilmu. Sebaliknya, Allah mengharamkan minuman keras yang memabukkan. Kalau larangan ini diabaikan, maka akan

\footnotetext{
${ }^{44}$ M akhrus M unajat, Dekonstruksi Hukum Pidana Islam, 5.

${ }^{45}$ Ibid., 6.
} 
terancam eksistensi akal. Di samping itu, ditetapkan adanya ancaman (hukuman dera 40 kali) bagi orang yang meminum minuman keras.

5. D an mâl (harta benda). Untuk memelihara harta ini disyariatkanlah tata cara pemilikan harta, misalnya dengan muamalah, perdagangan, dan kejja sama. Di samping itu, Allah mengharamkan mencuri atau merampas hak milik orang lain dengan cara yang tidak benar. Jika larangan mencuri diabaikan, maka pelakunya akan diancam dengan hukuman potong tangan.

Suatu perbuatan dianggap jarîmah apabila unsur-unsurnya telah terpenuhi. U nsur-unsur ini dibagi menjadi dua, yaitu unsur umum dan unsur khusus. Unsur umum adalah unsur yang dianggap sebagai tindak pidana berlaku pada semua jarîmah, sedangkan unsur khusus hanya berlaku untuk masing-masing jarîmah dan berbeda antara jarîmah yang satu dengan yang lain. ${ }^{46}$

Suatu perbuatan baru dianggap sebagai tindak pidana apabila unsur-unsurnya telah terpenuhi dan pelaku penyebar berita hoax terdapat dalam kedudukannya sebagai orang yang bertanggung jawab dan pada perbuatan yang diperintahkan. Adapun syarat-syarat untuk pelaku mukallaf itu ada dua macam, yaitu: Pelaku sanggup memahami nas-nas syara' yang berisi hukum taklifi dan pelaku orang yang pantas dimintai pertanggung jawaban dan dijatuhi hukuman.

Di dalam hukum pidana Islam, terdapat tiga hukuman pidana jarîmah: yang pertama, jarîmah hudûd, suatu jarîmah yang dibentuknya telah ditentukan oleh syarak sehingga terbatas jumlahnya. ${ }^{47}$ Yang kedua, jarîmah qishâsh atau diat, seperti jarîmah hudûd, jarîmah qishâsh atau diat, telah ditentukan jenis maupun besar hukuman untuk jarîmah ini hanya satu untuk setiap jamaah. ${ }^{48}$ Yang ketiga, ta'zîr, adalah suatu dalam bentuk jarîmah, yang bentuk atau macam jarîmah serta hukuman dan sanksinya ditentukan oleh penguasa. ${ }^{49}$

Sanksi bagi pelaku penyebaran berita hoax atau berita bohong dalam hukum pidana Islam adalah ta'zîr. Para fukaha mengartikan ta'zîr dengan hukuman yang tidak ditentukan oleh al-Q ur'an dan hadis yang berkaitan dengan kejahatan yang melanggar hak Allah swt dan hak hamba yang berfungsi sebagai pelajaran bagi terhukum dan pencegahannya untuk

\footnotetext{
${ }^{46}$ Ahmad W ardi Muslich, Pengantar dan Asas Hukum Pidana Islam: Fikih Jinayah, (Jakarta: Sinar Grafika, 2004), 27.

${ }^{47}$ A. Djazuli, Fiqh Jinayah, (Jakarta: PT . Raja G rafindo Persada, 1996), 11.

${ }^{48} \mathrm{lbid}, 163$.

${ }^{49} \mathrm{lbid}$.
} 
tidak mengulangi kejahatan serupa. Hukuman ta'zîr boleh dan harus diterapkan sesuai dengan tuntutan kemaslahatan. Para ulama membagi jarîmah ta'zîr yakni yang berkaitan dengan hak Allah swt dan hak hamba. ${ }^{50}$

Yang dimaksud dengan kejahatan yang berkaitan dengan hak Allah adalah segala sesuatu yang berkaitan dengan kemaslahatan umum. Seperti membuat kerusakan di muka bumi, perampokan, pencurian, perzinaan, pemberontakan dan tidak taat kepada ulil amri. Sedangkan yang dimaksud dengan kejahatan yang berkaitan dengan hak individu adalah segala sesuatu yang mengancam kemaslahatan bagi seorang manusia, seperti tidak membayar utang dan penghinaan..$^{51}$

Syarat supaya hukuman ta'zîr bisa dijatuhkan adalah orang yang berakal saja. O leh karena itu, sudah jelas pasti pelaku penyebar berita hoax itu adalah orang yang berakal dan orang mukalaf hukuman ta'zîr bisa dijatuhkan kepada setiap orang yang berakal yang melakukan suatu kejahatan yang tidak memiliki ancaman hukuman hudud, baik laki-laki maupun perempuan, muslim maupun kafir, balig atau anak kecil yang sudah berakal (mumayyiz). Karena mereka semua selain anak kecil adalah termasuk orang yang sudah memiliki kelayakan dan kepatutan untuk dikenai hukuman. Adapun anak kecil yang sudah mumayyiz, maka ia dita'zîr, namun bukan sebagai bentuk hukuman, akan tetapi sebagai bentuk mendidik dan memberi pelajaran.

Dapat ditarik kesimpulan bahwa seorang yang melakukan tindak pidana harus memenuhi syarat-syarat yaitu berakal, cukup umur, mempunyai kemampuan bebas (muchtâr).

Di ihat dari segi pemberitaan hoax, apabila merujuk pada individu maka kejahatannya termasuk kejahatan individu dan mengancam kemaslahatan bagi seorang manusia apabila pemberitaan hoax berbau dengan SARA suku, agama, ras, dan golongan berarti termasuk kejahatan menyinggung hak Allah karena segala sesuatu yang berkaitan dengan kemaslahatan umum.

Pada dasarnya, hukum Islam menetapkan bahwa tindak pidanatindak pidana ta'zîr memiliki sekumpulan hukuman yang tingkat berat dan ringannya beragam.

Menurut penulis, pelaku tindak pidana pemberitaan hoax mendapat hukuman ta'zîr yang berupa hukuman kawalan tidak terbatas.

\footnotetext{
50 lbid.

51 Ibid., 166.
} 
Dalam hukuman kurungan tidak terbatas, terhukum terus dikurung sampai ia menampakkan tobat dan baik pribadinya atau sampai ia mati, bahwa masa hukuman kurungan tidak ditentukan terlebih dahulu karena hukuman ini tidak terbatas, bahkan sampai terhukum mati. Artinya, hukuman baru akan berakhir dengan kematian si terhukum atau taubatnya sebelum mati atau menjadi baik pribadinya.

\section{Simpulan}

Pelaku penyebar berita hoax di indonesia telah melanggar pasal 28 ayat 1 UU Nomor 11 Tahun 2008 Tentang Informasi dan Transaksi Elektronik, oleh karena itu perlu diberi sanksi terhadap para pelaku penyebar berita bohong tersebut. Sanksi pidana untuk pelaku penyebar berita $\mathrm{H}$ oax terdapat pada pasal 45 a yaitu hukuman pidana penjara paling lama 6 (enam) tahun dan/atau denda paling banyak R p. 1.000.000.000,00 (satu miliar rupiah).

Dalam perspektif hukum pidana I slam, melanggar pasal 28 ayat 1 U U N omor 11 T ahun 2008 T entang Informasi dan T ransaksi Elektronik merupakan tindakan yang mengarah pada pemberitaan bohong, fitnah dan sanksi bagi pelaku penyebaran berita hoax atau berita bohong dalam hukum pidana I slam adalah ta'zîr. J ika pelaku tindak pidana penyebaran berita hoax dalam ta'zîr dilihat dari segi dasar hukum (penetapannya), pelaku tindak pidana penyebaran berita hoax sepenuhnya diserahkan kepada ulil amri, baik jenis maupun sanksinya belum ditentukan oleh syarak. Pelaku tindak pidana pemberitaan hoax mendapat hukuman ta'zîr yang berupa hukuman kawalan tidak terbatas dan hukuman kurungan tidak terbatas. Dalam hal ini, terhukum terus dikurung sampai ia menampakkan taubat dan baik pribadinya atau sampai ia mati.

\section{D aftar Rujukan}

Adami, Chazawi. dan Ferdian Ardi. Tindak Pidana Pemalsuan. Jakarta: PT Rajagrafindo Persada, 2016.

Al-Q arni, 'Aid. T afsîr al-M uyassar. Jakarta: Q isthi Press, 2008.

Asghary, Basri Iba. Solusi AI-Q ur'an tentang Problema Sosial Politik Budaya. Jakarta: Rineka Cipta, 1994.

BBC. "M engapa polisi harus mempidanakan penulis Jokowi U ndercover?"http://www.bbc.com/indonesia/indonesia-38496945 di akses pada 9 maret 2017. 
Chazawi, Adami. \& Ardi Ferdian. Tindak Pidana Informasi dan T ransaksi

Elektronik. M alang: M edia N usa C reative, 2015.

D epartemen Agama RI. Al-Q ur'an dan T erjemahannya. Semarang: CV

Toha putra, 1971.

dictionary.cambridge,

http://dictionary.cambridge.org/dictionary/english/hoax\#ranslatio

ns, diakses tanggal 20 A pril 2017.

D jazuli, A. Figh Jinayah. Jakarta: PT . Raja G rafindo Persada, 1996.

H amzah, Andi. Bunga Rampai H ukum Pidana dan Acara Pidana. Jakarta:

Ghalia Indonesia, 2001.

H oaxbuster. http://www.hoaxbusters.org/hoax10.html, diakses tanggal 04 april 2017.

J awapos http://www.jawapos.com/read/2017/04/06/121421/tersangka-

penyebar-berita-hoax-di-bandung-terancam-denda-rp-1-miliar ${ }_{2}$

diakses pada 06 april 2017.

Khallaf, Abdul W ahab. IImu U shul Fiqih. Semarang: D ina U tama, 1994.

Lamintang, P.A.F. D asar-D asar H ukum Pidana Indonesia. Bandung: PT.

Citra Adityta Bakti, 1996.

M askum. Kejahatan Cyber Crime. Jakarta: Kencana Pranada M edia Group, 2017.

M unajat, Makhrus. D ekonstruksi Hukum Pidana I slam. Yogyakarta: Logung Pustaka, 2004.

M uslich, Ahmad W ardi. Pengantar dan Asas H ukum Pidana I slam: Fikih Jinayah, Jakarta: Sinar G rafika, 2004.

Nasional Republika. "Hoax Merupakan Kabar Direncanakan" http://nasional.republika.co.id/berita/nasional/hukum/17/01/11/o jm2pv361-ahli-hoax-merupakan-kabar-yang-direncanakan ${ }_{L}$ diakses pada 19 maret 2017.

N ovita, Clara. Literasi M edia Baru dan Penyebaran Informasi H oax Studi Fenomenologi Pada Pengguna Whatsapp dalam Penyebaran Informasi H oax Periode Januari-maret 2015. Tesis Yogyakarta: Universitas Gadjah M ada, 2016.

Purwoleksono, Didik Endro "Seminar Peran Aktif Masyarakat Mengbadapi Hoax di Media Sosial, Peran Aktif Masyarakat M engbadapi H oax di M edia Sosial "16 M aret 2017".

Remmelink, Jan. H ukum Pidana (Komentar atas Pasal-Pasal Terpenting dari Kitab Undang Undang Hukum Pidana Belanda dan 
Padanannya dalam Kitab Undang-Undang Pidana Indonesia). Jakarta: Gramedia Pustaka, 2003.

Sa'udi, H assan. \& Ahmad H asan I rabi. Jerat-J erat Lisan. Solo: Pustaka Arofah, 2004.

Solissa, A. Basir. "Kemajuan Barat dan Reaksi Dunia Islam dalam Pandangan Bhasan Tibbi," Jurnal Refleksi, vol. 2, N o. 2, Juli 2002. Syarifuddin, Amir. M eretas Kebekuan Ijtihad. Jakarta: Ciputat Press, 2002.

Undang-Undang Nomor 11 Tahun 2008 tentang Informasi dan Transaksi Elektronik. 